\title{
비알코올지방간질환과 간세포암종
}

오현우 ${ }^{1,2}$. 전대원 ${ }^{1}$

${ }^{1}$ 한양대학교 의과대학 내과학교실, ${ }^{2}$ 국군청평병원

\section{Non-alcoholic Fatty Liver Disease and Hepatocellular Carcinoma}

\author{
Hyunwoo Oh' ${ }^{1,2}$, Dae Won Jun ${ }^{1}$ \\ 'Department of Internal Medicine, Hanyang University College of Medicine, Seoul; ${ }^{2}$ Korean Armed Forces Cheongpyeong Hospital, \\ Gapyeong, Korea
}

Received Jul. 17, 2017

Revised Aug. 16, 2017

Accepted Aug. 19, 2017
Hepatocellular carcinoma (HCC) is one of the most common life-threatening cancers worldwide. Recently, many patients with non-alcoholic fatty liver disease (NAFLD) and non-alcoholic steatohepatitis (NASH) have progressed to HCC even in the absence of cirrhosis. As the morbidity of metabolic syndrome increases, the proportion of HCC associated with NAFLD is expected to increase gradually. A new mechanism for the development of HCC in NAFLD has been identified; Diabetes mellitus, insulin resistance, obesity, lipotoxicity, gut dysbiosis are risk factors. Inflammatory cytokines such as adipokines, leptin, tumor necrosis factor-a, interlukin-8, nuclear factor-KB constitute dysplasia-carcinoma sequence. At the time of diagnosis, NAFLD/ NASH related HCC tend to progress to larger and in advanced tumor-node-metastasis stages compared to viral hepatitis related HCC. But there are no guidelines for early detection of NAFLD-related HCC. So, it is essential to study the screening program for the early detection of NAFLD-related HCC and precise methods for NAFLD. (J Liver Cancer 2017;17:117-125)

Keywords: Hepatocellular carcinoma; Non-alcoholic fatty liver disease; Metabolic syndrome X

\section{서 론}

간암(Liver cancer)은 전 세계에서 남성에서 다섯 번째, 여 성에서 아홉 번째로 자주 발생하며 암으로 인한 사망원인 중 $9.1 \%$ 를 차지, 2순위로 예후가 불량하다. ${ }^{1}$ 간암 중 간세포암 종(hepatocellular carcinoma, HCC)이 75-90\%를 차지한다. ${ }^{2}$ 지역에 따른 차이는 있지만, 전 세계적으로 간세포암종 발생 의 주 원인은 B형간염 바이러스 및 C형간염 바이러스에 의

\section{Corresponding author: Dae Won Jun}

Department of Internal Medicine, Hanyang University College of Medicine, 222 Wangsimni-ro, Seongdong-gu, Seoul 04763, Korea

Tel. +82-2-2290-8338, Fax. +82-2-972-0068

E-mail; noshin@hanyang.ac.kr

http://orcid.org/0000-0002-2875-6139
한 만성적인 간질환이다. ${ }^{3} \mathrm{~B}$ 형간염 바이러스의 경우 항바이 러스제제를 사용하며 바이러스를 억제해 간경변환자에서 간세포암종의 발생률을 $13.7 \%$ 에서 $3.7 \%$ 까지 줄일 수 있을 것으로 기대되고, ${ }^{4} \mathrm{C}$ 형간염 바이러스 역시 치료를 통해 전 원인 사망률을 $54 \%$ 감소시켜 이에 의한 간세포암종의 발생 은 감소할 것으로 보여진다. ${ }^{5} \mathrm{Kwak}$ 등의 국내연구에 의하면, 국내 간세포암종의 주요 원인은 B형간염 바이러스( $74.0 \%)$ 와 C형간염 바이러스(9.4\%)이며, ${ }^{6} 2017$ 년 한국 암 발생률 예 측에서 간세포암종은 남자에서는 4 위, 여자에서는 6 위를 차 지했고 간세포암종으로 인한 사망률은 2 위였다. ${ }^{7,8}$

최근 비알코올지방간질환에 의한 간세포암종이 증가하며 새로운 이슈가 되고 있다. 최근 한 체계적 문헌 고찰에 의하 면 비만환자의 증가로 미국에만 750-1,000만의 인구가 비알 코올지방간질환이라 추정하고 있으며, 간경변 없이도 비알 
코올지방간질환에 의한 간세포암종의 발병률이 $50 \%$ 까지 상승할 수 있다고 경고하고 있다. ${ }^{9}$ 기존의 연구에서는 간암 환자에서 대사질환의 교차비가 2.8 로 다른 원인에 비해 비 교적 작았으나 증가하는 유병률을 감안하면 비알코올지방 간질환이 간암의 주요원인으로 부각될 것으로 우려된다. ${ }^{10}$ 또한 50 세 이상의 당뇨 혹은 비만 환자 중 $60 \%$ 가 섬유화가 진행된 비알코올지방간염(steatohepatitis)을 않고 있으나 이 에 대한 유효한 치료법은 정립되지 않아 비알코올지방간염 환자의 약 $25 \%$ 가 간경변증으로 진행하며 다시 간경변증의 $10-25 \%$ 가 간세포암종으로 진행될 것으로 예측되어 이에 대 한 대처가 필요하다. ${ }^{11}$ 이에 본 종설에서는 비알코올지방간 질환에서 간세포암종 발생의 증가추세와 위험인자, 기전 그 리고 임상적 특징에 대해 알아보고자 한다.

\section{본 론}

\section{1. 비알코올지방간질환과 간경변증}

지방간의 정의는 전체 간세포에서 지방을 포함하는 간세 포의 비율이 $5 \%$ 이상인 경우로 정의한다. 비알코올지방간 질환은 유의한 만성적 음주(최근 2년, 주당 남성 > 21 표준 잔, 여성 >14 표준잔, 표준잔: 약 맥주 $340 \mathrm{~g}$ ) 없이 알코올
간염과 유사한 조직 소견을 보이는 질환이다. ${ }^{12}$ 비알코올지 방간질환은 간 내 염증의 유무에 따라 단순 지방간(simple steatosis)과 지방간염으로 나눌 수 있다. Lee 등에 의한 생검 이 시행된 589 명의 환자를 대상으로 한 연구에서, 비알코올 지방간의 유병률은 $51.4 \%$, 비알코올지방간염의 유병률은 약 $2.2 \%$ 로 보고되었는데 비알코올지방간과 비알코올지방 간염의 유병률은 문헌에 따라 다양하게 보고된다(Fig. 1). ${ }^{13}$

비알코올지방간질환 환자 중 간내 염증 간경변이 진행되 는 환자들의 특징에 대해서는 명확히 밝혀지지 않았다. Torres 등은 11 개의 연구를 포함한 메타분석에서 비알코올 지방간염이 있는 경우가 단순 지방간에 비해 의미 있는 섬 유화(significant fibrosis, Meta-analysis of Histological Data in Viral Hepatitis [METAVIR] $\geq$ F2)의 발생이 더 많음을 보 였으며, ${ }^{14} \operatorname{Singh}$ 등의 체계적 문헌 고찰 및 메타분석에서는 단순 지방간 환자에서는 연간 평균 섬유화 진행이 0.07 stage/year, 비알코올지방간염이 동반된 환자에서는 연간 평 균 섬유화 진행이 0.14 stage/year로 더 빨리 진행됨을 보였 다. ${ }^{15}$ 이와 같이 염증의 유무가 간경변 진행의 주요 위험인자 로 생각된다.

과체중 환자에서 간생검을 한 Ratziu 등의 연구에 의하면, 50세 이상의 연령(교차비 14.1), 높은 체질량지수(body mass index [BMI]) $\geq 28 \mathrm{~kg} / \mathrm{m}^{2}$ (교차비 5.7), 중성지방 $\geq 1.7$

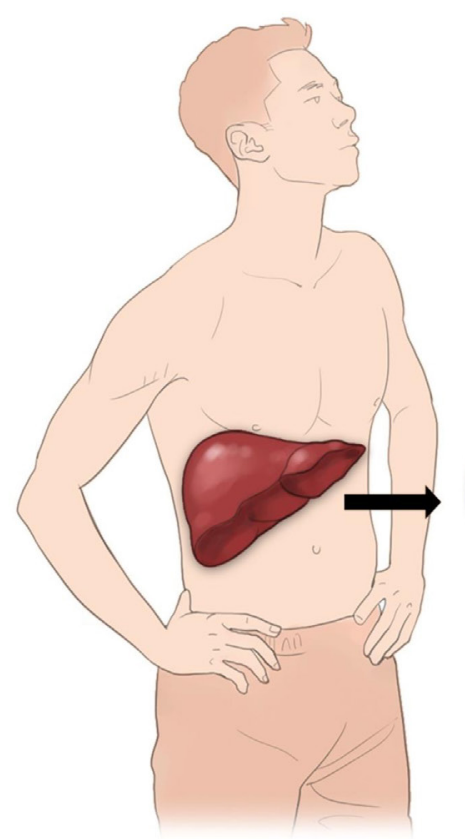

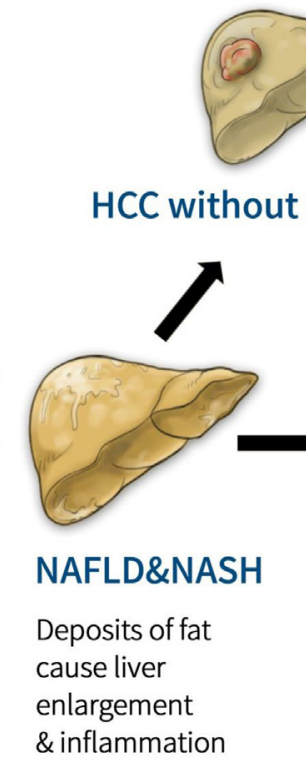

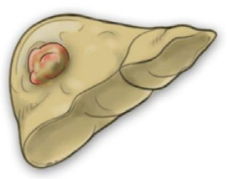

CC without Cirrhosis

NAFLD\&NASH

Deposits of fat cause liver \& inflammation

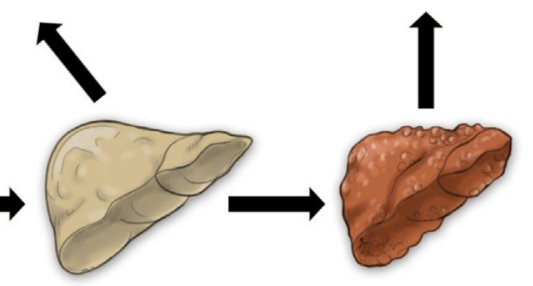

Liver Fibrosis Scar tissue forms. More liver cell injury occurs.

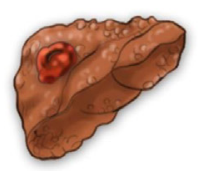

HCC with Cirrhosis

Cirrhosis

Scar tissue makes liver hard and unable to work properly.

Figure 1. Stages of NAFLD, NAFLD related HCC. NAFLD, non-alcoholic fatty liver disease; NASH, non-alcoholic steatohepatitis; HCC, hepatocellular carcinoma. 
$\mathrm{mmol} / \mathrm{L}$ (교차비 5.0)가 섬유화 진행의 위험인자였으며, ${ }^{16}$ Hossain 등의 연구에서 다변량 분석을 통해 중증도 이상의 섬유화 진행을 예측할 지표로 당뇨와 간세포 효소 수치의 증가를 볼 수 있었다. ${ }^{17}$ 또한 142 명의 생검으로 증명된 비알 코올지방간질환 환자를 대상으로 한 Petta 등의 연구에서는 내장 비만의 양이 많을수록, 그리고 homeostatic model assessment (HOMA) 수치가 높을수록 섬유화의 위험도가 커 졌다. ${ }^{18}$

\section{2. 비알코올지방간질환에서 간세포암종}

Oh 등은 간경변 환자에서 1993-1995년과 2000-2002년의 간세포암종환자를 비교한 연구에서 원인미상의 환자군의 비율이 증가하는 것을 관찰하였다 $(2.2 \%$ vs. $5.4 \%, P$ $<0.05) .{ }^{19} \mathrm{Cho}$ 등에 의해 시행된 원인이 불분명한(non-B non-C, non-alcohol) 간세포암종 환자 329명을 대상으로 한 후향적 코호트 연구에 의하면, B형간염 핵항체 양성 간세포 암종 환자들은 2001-2005년 86.6\%에서 2006-2010년 67.4\% 로 점차 감소 추세를 보였으나 비알코올지방간질환 연관 간세포암종 환자들은 2001-2005년 3.8\%에서 2006-2010년 $12.2 \%$ 로 증가하는 양상을 보였다. ${ }^{20}$ 가장 최근의 국내 연구 에서는 원인미상의 간세포암종의 비율이 $9.5 \%$ 로 제시되었 다. ${ }^{6}$ 일본의 경우에도, $\mathrm{C}$ 형간염바이러스 감염이 전체 간세 포암종 중 $67 \%$ 를 차지하는 주 원인이었으나 비만 및 대사 증후군 환자가 증가함에 따라 $\mathrm{C}$ 형간염에 의한 간세포암종 환 자수는 지속적으로 감소하고 있으며 비바이러스감염 간 질환에 의한 간세포암종 환자는 1991년 10\%에서 2010년 $24.1 \%$ 으로 점차적으로 증가하였다. ${ }^{21}$

\section{3. 비알코올지방간질환에 의한 간세포암종의 발생률 및 사망률}

여러 나라에서 시행된 연구들을 비교해 보았을 때 비알코 올지방간질환에 의한 간세포암종의 발생률 및 사망률은 다 양하게 보고되고 있다. ${ }^{22}$ 그러나 각 연구들은 연구방법에 차 이가 있으며 연구에 포함된 환자들의 특성이 다양해(섬유 화 정도의 차이, 지방침착의 정도, 혈청 효소수치, 평균 관찰 기간 등) 객관적인 비교가 어려워 해석에 유의해야 한다.

Younossi 등은 최근 메타분석을 통해 비알코올지방간 환 자군에서 연간 간세포암종 발생률이 1,000 인년당 0.44 , 비알 코올지방간염 환자군에서는 1,000 인년당 5.29 로 비알코올
지방간염에서 위험도가 더 높음을 보였다. ${ }^{23}$ 미국에서 195 명 의 비알코올지방간염에 의한 간경변 환자들을 관찰한 연구 에서는 2003-2007년 복부 전산화단층촬영 및 혈청 alpha-fetoprotein $(\mathrm{AFP})$ 를 지속적으로 추적한 결과 $12.8 \%(\mathrm{n}=25)$ 에 서 간세포암종이 발병하였으며 연간 $2.6 \%$ 의 누적발병률을 보였다. ${ }^{24}$ Hashimoto 등은 비알코올지방간염으로 인한 진 행된 섬유화가 동반된 간암환자에서 전향적 코호트 연구를 통해 5 년간 $7.6 \%$ 의 누적 간세포암종 발생률을 보였고, ${ }^{25}$ 일 본의 60세 이상 성인 비알코올지방간/비알코올지방간염 환 자들을 대상으로 한 코호트 연구에서는 평균 8.2년의 관찰 주기 동안 비알코올지방간질환에 의한 누적 간세포암종 발 생률이 $6 \%$ 임을 보였다. ${ }^{26}$ 스웨덴의 한 코호트 연구에서는 118 명의 비알코올지방간질환 환자를 21 년간 추적관찰하여 비알코올지방간에 의한 누적 간세포암종 사망률이 $3 \%$, 비 알코올지방간염에 의한 누적 간세포암종 사망률은 $6 \%$ 임을 보였다. ${ }^{27}$

\section{4. 간경변증을 동반하지 않은 비알코올지방간질환에서 간세포암종의 발생}

비알코올지방간질환에 의한 간세포암종은 간경변의 동 반 없이 발생될 수 있다고 알려져 있다. Paradis 등은 프랑스 에서 128 명의 간세포암종 절제수술을 받은 환자를 대상으 로 한 연구에서 31 명의 비알코올지방간질환 연관 간세포암 종 환자 중 $65.5 \%(\mathrm{n}=20)$ 은 F2 이하의 섬유화 단계(METAVIR F0-F2)를 보였다. ${ }^{28}$ 또한 유의한 섬유화가 동반되지 않 은 간세포암종 환자군에서 간경변을 동반한 경우보다 간세 포암종의 크기는 유의하게 더 컸고 $(10.1 \pm 6.7 \mathrm{~cm}$ in F0-F2 vs. $6.6 \pm 3.5 \mathrm{~cm}$ in F3-F4) 분화도도 더 높았다. ${ }^{28}$

그러나 일반적으로 진행된 섬유화는 간세포암종의 발생 률을 높인다고 알려져 있다. 일본에서 14,530명의 간세포암 종 환자를 대상으로 시행된 코호트 연구에서, 생검에 의해 진단된 비알코올지방간질환에 의한 간세포암종 환자는 292 명으로 약 $2 \%$ 였다. 비알코올지방간질환에 의한 간세포 암종 292명 중 111 명은 간경변이 없었으며, 181 명에서는 간 경변이 동반되어 있었다. ${ }^{29}$ White 등의 비알코올지방간질환 에 의한 간세포암종에 대한 메타분석에서 비알코올지방간 질환에 의해 발생한 간세포암종 환자의 $60 \%$ 에서 간경변이 동반되어 있었다. ${ }^{30}$ 또한 비알코올지방간염에 의한 간경변 에서 간세포암종의 발병률이 $2.4-12.8 \%$ 증가하였다. ${ }^{30}$ 


\section{5. 비알코올지방간질환에 의한 간세포암종의 임상적 특성}

비알코올지방간질환에 의한 간세포암종의 특성은 연구 자에 따라 다양한 결과를 보인다. 미국에서 83 명의 비알코 올지방간질환 간세포암종 환자들을 대상으로 한 후향적 코 호트 연구에 의하면, 36 명의 간경변이 동반되지 않은 환자 와 47 명의 간경변이 동반된 환자를 비교했을 때, 간경변이 동반되지 않은 환자군은 상대적으로 연령이 높고(67.5 \pm 12.3세 vs. $62.7 \pm 8.1$ 세) 비만과 2형당뇨의 유병률이 낮았다 $(52 \%$ vs. $83 \%, 38 \%$ vs. $83 \%)$. 또한 단일병변( $80.6 \%$ vs. $52.2 \%)$ 으로 비교적 더 큰 병변을 보여(>5 cm, $77.8 \%$ vs. $10.6 \%)$ 간절제를 받는 비율이 높았고 재발도 $14 \%$ 에 그쳐 상대적으로 예후가 좋았다. 그러나 지방 축적의 양과 염증, 섬유화 정도와 중증도는 일치하지는 않았다. ${ }^{31}$ White 등의 메타분석에서 비알코올지방간질환 간세포암종 환자의 코 호트 비교에서 고령, 흡연, 그리고 혈중 포도당수치가 간세 포암종 발생의 독립적인 위험인자였다. ${ }^{30} \operatorname{Rim}$ 등에 의한 국 내 연구에 의하면 원인미상의 간세포암종은 당뇨, 고혈압, 대사증후군의 유병률이 높고 체질량지수가 높게 나타나며
진단 당시의 연령이 높았다. ${ }^{32}$ 국내연구에서는 여성의 비중 이 높았으나 Cholankeril 등에 의한 문헌고찰에서 비알코올 지방간질환에서 발생한 간세포암종에 대한 논문들을 비교 한 바에 의하면 상대적으로 발병연령이 높고 남성에서의 발 병률이 더 높았다. ${ }^{33}$

이와 같이 비알코올지방간질환에 의한 간세포암종 발생 환자에서 대사증후군 혹은 각각의 구성요소들의 연관성이 관찰된다. 하지만 국내 국민건강보험의 건강검진 자료를 이 용한 한 연구에서, $40-79$ 세의 112,794 명의 성인의 자료를 분 석한 결과 대사증후군 진단 구성요소들의 개수와 간세포암 종 발생률은 유의한 연관관계가 없었다. 위험인자에 대한 단변량분석에서는 고혈압(위험비 hazard ratio: 1.184), 공복 혈당(위험비 1.256) and 총 콜레스테롤(위험비: 0.676)이 통 계적으로 유의한 연관이 있었다. ${ }^{34}$

\section{6. 비알코올지방간질환에 의한 간세포암종의 위험인 자와 발생기전}

비알코올지방간/비알코올지방간염 연관 간세포암종은 대사증후군과 깊이 연관되어 있다. 비알코올지방간질환은

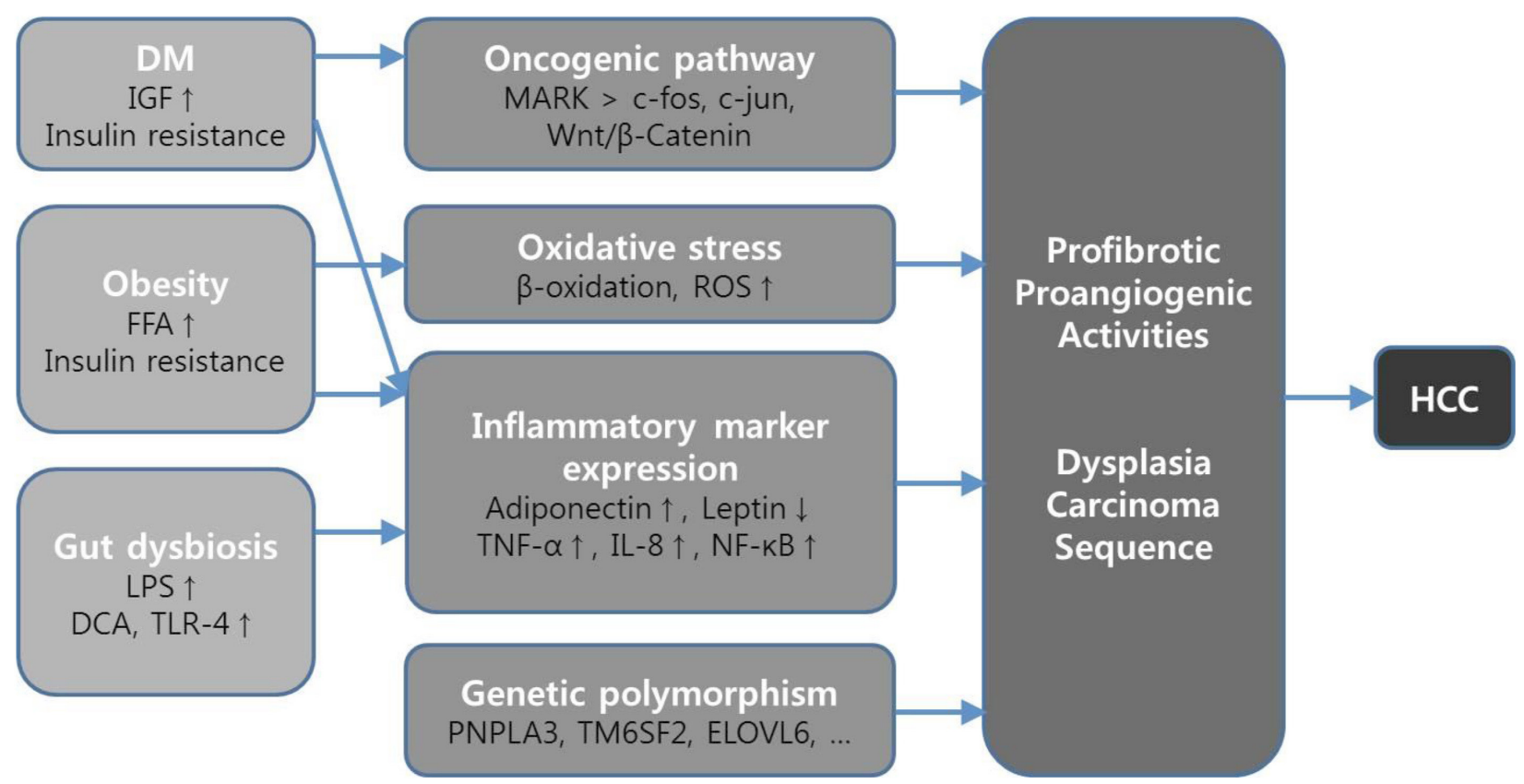

Figure 2. Pathogenesis of hepatocellular carcinoma in non-alcoholic fatty liver disease. DM, diabetes mellitus; IGF, insulin like growth factor; FFA, free fatty acid; LPS, lipo-polysaccarride; DCA, deoxycholic acid; TLR-4, toll-like receptor-4; MARK, mitogen-activated protein kinase; ROS, reactive oxygen species; TNF- $\alpha$, tumor necrosis factor- $\alpha$; IL-8, interlukin-8; NF- $\kappa B$, nuclear factor- $\mathrm{B}$; PNPLA3, patatin-like phospholipase domain-containing protein 3; TM6SF2, transmembrane 6 superfamily 2 human gene; ELOVL6, ELOVL fatty acid elongases 6; HCC, hepatocellular carcinoma. 
비만, 제 2 형 당뇨병, 이상지질혈증, 대사 증후군 등과 밀접 한 연관성을 보이며, 비알코올지방간질환 환자의 $90 \%$ 에서 대사증후군의 요소 중 한 가지 이상을 가지고 $1 / 3$ 에서 대사 증후군을 동반한다. ${ }^{35}$ 이와 같은 만성적인 염증에 의해 세포 및 유전자 손상이 진행되어 발생하는 이형성-암화 과정 (dysplasia-carcinoma sequence)에 의한 발암현상이 간세포 암종 발생의 대표적인 기전으로 제시되고 있다(Fig. 2). ${ }^{33}$

\section{1) 고인슐린혈증과 당뇨}

고인슐린혈증과 당뇨가 간세포암종 발생의 독립적인 위 험인자라는 사실은 이미 잘 알려져 있으며, 비알코올지방간 질환의 중요발생기전 중 하나이다. Welzel 등은 미국에서 68세 이상의 간세포암종 진단환자 6,991명을 대상으로 한 연구에서 간세포암종에 대한 당뇨의 교차비를 2.47 라 하였 고 $^{36}$, Turati 등은 이탈리아에서 185 명의 간세포암종 환자가 포함된 환자-대조군연구에서 간세포암종에 대한 당뇨의 교 차비를 4.33 이라 하였다. ${ }^{37}$ 위와 같은 연관성은 다음과 같은 기전을 통해 설명된다. 간내지방축적 및 비만은 인슐린저항 성을 유발하고 이는 곧 고인슐린혈증으로 이어진다. 인슐린 과 인슐린 유사 성장 인자(insulin like growth factor, IGF)는 여러 종양경로를 활성화시키는데, 그중 대표적으로 mitogen-activated protein kinase (MARK) 경로는 전암유전자로 알려진 c-fos, c-jun의 전사를 증가시키고, ${ }^{22} \mathrm{Wnt} / \beta$-Catenin 단계를 활성화해 섬유화 및 간세포암을 유발한다. ${ }^{38}$ 이에 따 라 HOMA와 C-peptide 수치가 간세포암종의 고위험군 환 자와 연관이 있다고 여겨지고 있다. ${ }^{22,39,40}$

\section{2) 비만과 지방독성}

비만은 간세포암종을 포함한 여러 암들의 중요한 위험 인 자이며 비만은 인슐린 저항성, 장내균주 등 여러 위험인자 와 영향을 주고 받는다. 그러나 비만의 체질량지수의 기준 은 연구별로 다양해 논문을 해석할 때 유의해야 한다. 물론 비만은 모든 암에서 동반될 수 있는 위험인자이다. 국내연 구에서 $\mathrm{Oh}$ 등의 연구에서는 체질량지수가 $30 \mathrm{~kg} / \mathrm{m}^{2}$ 이상인 환자에서는 정상 체질량지수 환자(BMI 18.5-22.9 kg/m²)들 에 비해 모든 암의 발생률이 $26 \%$ 증가하였다. ${ }^{41}$ 체질량지수 가 $30 \mathrm{~kg} / \mathrm{m}^{2}$ 이상인 환자에서 간세포암종(간내담관암 제 외) 발생의 상대위험도는 1.56 였다. ${ }^{41}$ Borena 등은 노르웨이 에서 시행한 코호트 연구에서 간세포암종의 비만에 대한 상 대위험도를 1.39 라 보고하였고, ${ }^{42}$ Turati 등은 간세포암종에 대한 비만의 교차비를 1.97 이라 하였다. ${ }^{37}$ Schlesinger 등의
유럽 10개 국가에서 25-70세의 성인을 대상으로 8.6년의 추 적관찰기간 동안 177 명의 간세포암종 환자를 대상으로 한 전향적 코호트 연구에서 환자군을 체질량지수에 따라 삼분 위로 나누어 비교하여, 간세포암종에 대한 상대위험도를 과 체중 1.28 , 비만 2.19, 복부둘레 2.03, Waist-to-Hip Ratio (WHR) 1.96으로 비만지표와도 연관관계가 있음을 보였 다. ${ }^{43}$

일반적으로 비만 환자에서는 아디포넥틴(adiponectin)이 감소하고 렙틴(leptin)이 증가하는데 항염증사이토카인인 아디포넥틴이 감소하면, 쿠퍼세포나 대식세포의 내독소에 의한 염증신호전달이 가속화되고 이로 인해 종양의 혈관형 성을 막을 수 없게 된다. ${ }^{44}$ 또한 비만과 과도한 내장 지방 조 직은 렙틴 수치를 증가시키고 이는 만성 염증을 유발한다. 렙틴은 섬유화촉진(profibrotic) \& 혈관신생촉진(proangiogenic)의 특징을 가지는 사이토카인으로 야누스 키나제(janus kinase, JAK) 경로를 활성화하여 염증반응물질들을 활 성화시킨다. ${ }^{45}$

한편 지방조직의 증가는 지방독성을 야기하는데, 말초지 방조직, 식이, 간내 지방산 합성 등에 의해 간내 지방축적이 증가하면 유리지방산의 증가로 이어진다. ${ }^{46}$ 지방산(fatty acid)의 과다한 침착은 베타산화( $\beta$-oxidation) 과정을 통해 활성산소를 증가시키고 이는 소포체의 스트레스를 유발해 세포의 신호 전달체계를 어지럽히고, 유전자의 전사에 영향 을 주어 종양의 발생을 촉진시킨다. ${ }^{47}$

비알코올지방간질환은 이와 같은 비만 및 관련 대사이상 과 연관하여 간세포암종 이외에도 여러 암의 발생률을 높이 는 것으로 생각된다. 특히 간, 대장, 식도, 위, 췌장 등의 소화 기계 암종과 남성에서는 신장, 여성에서는 유방암과 연관관 계를 보였다. ${ }^{48}$

\section{3) 장 세균총 이상(Gut dysbiosis)}

최근 장내 미생물군유전체(Gut microbiome)에 대한 연구 가 활발해져 많은 질환과의 연관성이 연구되고 있는데, 비 알코올지방간염 환자에서도 소장세균 과증식과 종양괴사 인자(tumor necrosis factor- $\alpha$, TNF- $\alpha$ ), 인터루킨-8 (interlukin, IL-8)와 같은 사이토카인의 증가 및 지질다당체(lipopolysaccarride, LPS)를 인식해 핵 인자- $\kappa \mathrm{B}$ (nuclear factor$\kappa \mathrm{B}, \mathrm{NF}-\kappa \mathrm{B})$ 등 염증성 사이토카인을 증가시키는 TLR-4 의 발현이 증가되어 있다는 연구들이 발표되었다. ${ }^{49,50}$

Yoshimoto 등은 동물실험에서 비만으로 인한 장내세균 총의 변화에서 deoxyribonucleic acid (DNA)의 손상을 유발 
해 간내 염증 및 종양유발인자를 활성화하는 디옥시콜산 (deoxycholic acid, DCA)의 증가를 관찰하였고, ${ }^{51}$ Dapito 등 은 동물실험에서 지질다당체를 통한 toll-like receptor-4 (TLR-4)의 활성화가 간세포암종의 증식을 매개하고, 세포 자멸사를 막는 것을 관찰해 새로운 치료대상이 될 수 있음 을 보여 장내 세균총의 조절을 통한 지질다당체의 제거가 새로운 치료법이 될 가능성을 제시하였다. ${ }^{52}$

\section{4) 유전자 다양성(Genetic polymorphism)}

최근 비알코올지방간질환과 간세포암종에 대한 전유전 체 연관성 연구(genome-wide association studies, GWAS) 또 한 활발히 시행되고 있다. ${ }^{53}$ PNPLA3 gene은 비알코올지방 간질환에서 비알코올지방간염 위험도가 3.5 배 높고, 섬유화 위험도가 3.3 배 높은 것으로 나타났는데, ${ }^{54}$ 일본에서 시행된 Ueyama 등의 연구에서는 PNPLA3에 위치한 단일염기변이 rs738409가 당뇨가 동반된 간세포암종 환자군에서 유의하 게 증가해 있었으며(교차비 2.53) 여러 암의 발병에 있어 중 요한 역할을 하는 JAZF1 유전자와도 유의한 연관이 있는 것 으로 생각된다 하였다(교차비 3.44 ) ${ }^{55} \mathrm{Liu}$ 등은 조직검사를 통해 비알코올지방간질환이 증명된 환자들이 포함된 코호 트 연구를 통해 TM6SF2 저빈도 유전자형 발현이 비알코올 지방간질환과 연관이 있음을 밝혔다. ${ }^{56} \mathrm{TM} 6 \mathrm{SF} 2$ 의 발현은 중성지방 수치와 간경변의 중증도와 유의한 연관성이 있었 으며, 연령, 성별, 당뇨, 간경변 등의 위험인자가 포함된 다 변량 분석에서는 유의성이 없었으나 단변량 분석에서는 비 알코올지방간질환 연관 간세포암종으로의 진행위험이 증 가되었다(교차비 1.92). 또한 Kessler 등은 동물실험과 비알 코올지방간질환 연관 간세포암종 환자의 간조직표본을 이 용한 연구에서, 비알코올지방간염 및 비알코올지방간염 연 관 간세포암종환자에서 지방산 신장 효소인 ELOVL6의 발 현이 증가되어 있는 등 다방면에서 연구가 진행되고 있다..$^{57}$

\section{5) 기타}

간내 철 축적은 비알코올지방간염에서 간세포암종의 진 행과 연관이 있었다. Sorrentino 등은 염증을 동반한 간세포 암종 환자에서 염증의 정도는 간세포, 동모양세포 등의 철 침착량과 연관이 있다고 하였다. ${ }^{58}$ Dongiovanni 등은 철분 과다증후군(dysmetabolic iron overload syndrome, DIOS)이 대사증후군 및 비알코올지방간질환의 발생빈도를 높인다 고 보고하였다. ${ }^{59}$ 이는 산화 자유 라디칼 반응에 의한 DNA 손상과 연결되는 것으로 생각된다. ${ }^{60}$ 또한 Kowdley 등은 간
내 철 침착량과 연관되어 상승하는 페리틴(ferritin) 수치가 비알코올지방간질환에서 진행된 간섬유화가 동반되었을 경우 증가(교차비 1.66)한다고 보고하였다. ${ }^{61}$

알코올 섭취와 비알코올지방간염에서 간세포암종의 발 생에 대해서는 논쟁의 여지가 있다. Ascha 등은 다변량 콕스 비례 위험 회귀분석을 통해 어떤 형태의 음주에서도 간세포 암종의 발생률이 증가하며 3.6배의 간세포암종 발생위험이 증가한다고 하였으나, ${ }^{24}$ Dunn 등은 하루 $20 \mathrm{mg} /$ 일 미만의 알코올을 섭취하는 군에서 음주하지 않는 군에 비해 비알코 올지방간염 유병률과 섬유화와 진행도가 낮다고 하였다. ${ }^{62}$ 단, 음주량의 정의와 분류가 연구마다 다르고 설문조사에 의존하게 되므로 객관적인 비교는 어렵다. 또한 관련연구는 적지만 Farges 등은 1993-2008년까지 218명의 간세포종(hepatocellular adenoma) 환자를 선발하여 그중 23 명에서 간세 포암종으로의 악성 변화를 관찰하였다. ${ }^{63}$ 대부분이 남성에 서 발생하였는데 이는 대사증후군 동반과 연관성이 있었고 그중 $2 / 3$ 에서는 $\beta$-Catenin 활성화가 관찰되어 간세포종의 악성변화 또한 하나의 가설로 받아들여지고 있다. ${ }^{63}$

\section{결 론}

최근 비만과 제 2 형 당뇨병의 유병률이 증가되며 비알코 올지방간질환의 유병률도 증가되면서 비알코올지방간질 환에 의한 간세포암종의 발생도 증가되고 있다. 그러나 비 알코올지방간질환 환자에서 간세포암종의 조기 발견을 위 한 선별검사가 필요한지 여부와, 그리고 간세포암종의 고위 험군을 선별할 수 있는 비침습적인 진단법에 대한 연구가 필요하다.

\section{Author contributions}

Manuscript writing: Hyunwoo Oh

Superviser: Dae Won Jun

\section{Conflicts of Interest}

The authors have no conflicts to disclose.

\section{REFERENCES}

1. Ferlay J, Soerjomataram I, Dikshit R, Eser S, Mathers C, Rebelo M, et al. Cancer incidence and mortality worldwide: sources, methods and 
major patterns in GLOBOCAN 2012. Int J Cancer 2015;136:E359-E386.

2. Wong MC, Jiang JY, Goggins WB, Liang M, Fang Y, Fung FD, et al. International incidence and mortality trends of liver cancer: a global profile. Sci Rep 2017;7:45846.

3. Balogh J, Victor D 3rd, Asham EH, Burroughs SG, Boktour M, Saharia $A$, et al. Hepatocellular carcinoma: a review. J Hepatocell Carcinoma 2016:3:41-53.

4. Hosaka T, Suzuki F, Kobayashi M, Seko Y, Kawamura Y, Sezaki H, et al. Long-term entecavir treatment reduces hepatocellular carcinoma incidence in patients with hepatitis B virus infection. Hepatology 2013;58:98-107.

5. Morgan RL, Baack B, Smith BD, Yartel A, Pitasi M, Falck-Ytter $Y$. Eradication of hepatitis $C$ virus infection and the development of hepatocellular carcinoma: a meta-analysis of observational studies. Ann Intern Med 2013;158(5 Pt 1):329-337.

6. Kwak HW, Park JW, Koh YH, Lee JH, Yu A, Nam BH. Clinical characteristics of patients with cryptogenic hepatocellular carcinoma in a hepatitis B virus-endemic area. Liver Cancer 2016;5:21-36.

7. Jung KW, Won YJ, Oh CM, Kong HJ, Lee DH, Lee KH. Prediction of cancer incidence and mortality in Korea, 2017. Cancer Res Treat 2017:49:306-312

8. Jung KW, Won YJ, Oh CM, Kong HJ, Lee DH, Lee KH, et al. Cancer statistics in Korea: incidence, mortality, survival, and prevalence in 2014. Cancer Res Treat 2017;49:292-305.

9. Rinella ME. Nonalcoholic fatty liver disease: a systematic review. JAMA 2015;313:2263-2273.

10. Makarova-Rusher OV, Altekruse SF, McNeel TS, Ulahannan S, Duffy $A G$, Graubard BI, et al. Population attributable fractions of risk factors for hepatocellular carcinoma in the United States. Cancer 2016;122:1757-1765.

11. Siegel $A B$, Zhu AX. Metabolic syndrome and hepatocellular carcinoma: two growing epidemics with a potential link. Cancer 2009;115:5651-5661.

12. Sanyal AJ, Brunt EM, Kleiner DE, Kowdley KV, Chalasani N, Lavine $J E$, et al. Endpoints and clinical trial design for nonalcoholic steatohepatitis. Hepatology 2011;54:344-353.

13. Lee JY, Kim KM, Lee SG, Yu E, Lim YS, Lee HC, et al. Prevalence and risk factors of non-alcoholic fatty liver disease in potential living liver donors in Korea: a review of 589 consecutive liver biopsies in a single center. J Hepatol 2007;47:239-244.

14. Torres DM, Williams CD, Harrison SA. Features, diagnosis, and treatment of nonalcoholic fatty liver disease. Clin Gastroenterol Hepatol 2012;10:837-858

15. Singh S, Allen AM, Wang Z, Prokop LJ, Murad MH, Loomba R. Fibrosis progression in nonalcoholic fatty liver vs nonalcoholic steatohepatitis: a systematic review and meta-analysis of paired-biopsy studies. Clin Gastroenterol Hepatol 2015;13:643-654. e1-e9; quiz e39-40.
16. Ratziu V, Giral P, Charlotte F, Bruckert E, Thibault V, Theodorou I, et al. Liver fibrosis in overweight patients. Gastroenterology 2000;118:1117-1123.

17. Hossain N, Afendy A, Stepanova M, Nader F, Srishord M, Rafiq N, et al. Independent predictors of fibrosis in patients with nonalcoholic fatty liver disease. Clin Gastroenterol Hepatol 2009;7:1224-1229, 1229. e1-e2.

18. Petta S, Amato MC, Di Marco V, Camma C, Pizzolanti G, Barcellona $M R$, et al. Visceral adiposity index is associated with significant fibrosis in patients with non-alcoholic fatty liver disease. Aliment Pharmacol Ther 2012;35:238-247.

19. Oh KC, Park SH, Park JC, Jin DK, Park CS, Kim KO, et al. Is the prevalence of cryptogenic hepatocellular carcinoma increasing in Korea?. Korean I Gastroenterol 2005;45:45-51.

20. Cho EJ, Kwack MS, Jang ES, You SJ, Lee JH, Kim YJ, et al. Relative etiological role of prior hepatitis $B$ virus infection and nonalcoholic fatty liver disease in the development of non-B non-C hepatocellular carcinoma in a hepatitis B-endemic area. Digestion 2011;84 Suppl 1:17-22.

21. Tokushige $K$, Hyogo $H$, Nakajima $T$, Ono $M$, Kawaguchi $T$, Honda $K$, et al. Hepatocellular carcinoma in Japanese patients with nonalcoholic fatty liver disease and alcoholic liver disease: multicenter survey. J Gastroenterol 2016;51:586-596.

22. Chettouh H, Lequoy M, Fartoux L, Vigouroux C, Desbois-Mouthon C. Hyperinsulinaemia and insulin signalling in the pathogenesis and the clinical course of hepatocellular carcinoma. Liver Int 2015;35:22032217.

23. Younossi ZM, Koenig AB, Abdelatif D, Fazel Y, Henry L, Wymer M. Global epidemiology of nonalcoholic fatty liver disease-Metaanalytic assessment of prevalence, incidence, and outcomes. Hepatology 2016;64:73-84.

24. Ascha MS, Hanouneh IA, Lopez R, Tamimi TA, Feldstein AF, Zein NN. The incidence and risk factors of hepatocellular carcinoma in patients with nonalcoholic steatohepatitis. Hepatology 2010;51:19721978.

25. Hashimoto E, Yatsuji S, Tobari M, Taniai M, Torii N, Tokushige K, et al. Hepatocellular carcinoma in patients with nonalcoholic steatohepatitis. J Gastroenterol 2009;44 Suppl 19:89-95.

26. Arase Y, Kobayashi M, Suzuki F, Suzuki Y, Kawamura Y, Akuta N, et al. Difference in malignancies of chronic liver disease due to non-alcoholic fatty liver disease or hepatitis $\mathrm{C}$ in Japanese elderly patients. Hepatol Res 2012;42:264-272.

27. Soderberg C, Stal P, Askling J, Glaumann H, Lindberg G, Marmur J, et al. Decreased survival of subjects with elevated liver function tests during a 28-year follow-up. Hepatology 2010;51:595-602.

28. Paradis V, Zalinski S, Chelbi E, Guedj N, Degos F, Vilgrain V, et al. Hepatocellular carcinomas in patients with metabolic syndrome often develop without significant liver fibrosis: a pathological analysis. 
Hepatology 2009;49:851-859.

29. Tokushige $K$, Hashimoto E, Horie Y, Taniai M, Higuchi S. Hepatocellular carcinoma in Japanese patients with nonalcoholic fatty liver disease, alcoholic liver disease, and chronic liver disease of unknown etiology: report of the nationwide survey. J Gastroenterol 2011;46:1230-1237.

30. White DL, Kanwal F, El-Serag HB. Association between nonalcoholic fatty liver disease and risk for hepatocellular cancer, based on systematic review. Clin Gastroenterol Hepatol 2012;10:1342-1359.e2.

31. Mohamad B, Shah V, Onyshchenko M, Elshamy M, Aucejo F, Lopez $\mathrm{R}$, et al. Characterization of hepatocellular carcinoma (HCC) in nonalcoholic fatty liver disease (NAFLD) patients without cirrhosis. Hepatol Int 2016;10:632-639.

32. Rim MY, Kwon OS, Ha M, Kim JS, Ko KI, Kim DK, et al. Clinical features of non-alcoholic fatty liver disease in cryptogenic hepatocellular carcinoma. Korean J Gastroenterol 2014;63:292-298.

33. Cholankeril G, Patel R, Khurana S, Satapathy SK. Hepatocellular carcinoma in non-alcoholic steatohepatitis: Current knowledge and implications for management. World J Hepatol 2017;9:533-543.

34. Ki M, Choi HY, Kim BH, Park JW. Risk of hepatocellular carcinoma in Korean patients with metabolic syndrome: a big data analysis [Abstract]. KASL 2016;1:31.

35. Marchesini G, Bugianesi E, Forlani G, Cerrelli F, Lenzi M, Manini R, et al. Nonalcoholic fatty liver, steatohepatitis, and the metabolic syndrome. Hepatology 2003;37:917-923.

36. Welzel TM, Graubard BI, Quraishi S, Zeuzem S, Davila JA, El-Serag $H B$, et al. Population-attributable fractions of risk factors for hepatocellular carcinoma in the United States. Am J Gastroenterol 2013;108:1314-1321.

37. Turati F, Talamini R, Pelucchi C, Polesel J, Franceschi S, Crispo A, et al. Metabolic syndrome and hepatocellular carcinoma risk. Br J Cancer 2013;108:222-228.

38. Siddique A, Kowdley KV. Insulin resistance and other metabolic risk factors in the pathogenesis of hepatocellular carcinoma. Clin Liver Dis 2011;15:281-296, vii-X.

39. Chao LT, Wu CF, Sung FY, Lin CL, Liu CJ, Huang CJ, et al. Insulin, glucose and hepatocellular carcinoma risk in male hepatitis $\mathrm{B}$ carriers: results from 17-year follow-up of a population-based cohort. Carcinogenesis 2011;32:876-881.

40. Aleksandrova K, Boeing H, Nothlings U, Jenab M, Fedirko V, Kaaks R, et al. Inflammatory and metabolic biomarkers and risk of liver and biliary tract cancer. Hepatology 2014;60:858-871.

41. Oh SW, Yoon YS, Shin SA. Effects of excess weight on cancer incidences depending on cancer sites and histologic findings among men: Korea National Health Insurance Corporation Study. J Clin Oncol 2005;23:4742-4754.

42. Borena W, Strohmaier S, Lukanova A, Bjorge T, Lindkvist B, Hallmans $G$, et al. Metabolic risk factors and primary liver cancer in a prospective study of 578,700 adults. Int J Cancer 2012;131:193-200.

43. Schlesinger S, Aleksandrova K, Pischon T, Fedirko V, Jenab M, Trepo $E$, et al. Abdominal obesity, weight gain during adulthood and risk of liver and biliary tract cancer in a European cohort. Int J Cancer 2013;132:645-657.

44. Brakenhielm E, Veitonmaki N, Cao R, Kihara S, Matsuzawa Y, Zhivotovsky $\mathrm{B}$, et al. Adiponectin-induced antiangiogenesis and antitumor activity involve caspase-mediated endothelial cell apoptosis. Proc Natl Acad Sci U S A 2004;101:2476-2481.

45. Procaccini C, Galgani M, De Rosa V, Carbone F, La Rocca C, Ranucci $G$, et al. Leptin: the prototypic adipocytokine and its role in NAFLD. Curr Pharm Des 2010;16:1902-1912.

46. Margini C, Dufour JF. The story of HCC in NAFLD: from epidemiology, across pathogenesis, to prevention and treatment. Liver Int 2016;36:317-324.

47. Vinciguerra $M$, Carrozzino $F$, Peyrou $M$, Carlone $S$, Montesano $R$, Benelli $R$, et al. Unsaturated fatty acids promote hepatoma proliferation and progression through downregulation of the tumor suppressor PTEN. J Hepatol 2009;50:1132-1141.

48. Sanna C, Rosso C, Marietti M, Bugianesi E. Non-alcoholic fatty liver disease and extra-hepatic cancers. Int J Mol Sci 2016;17. pii: E717.

49. Wigg AJ, Roberts-Thomson IC, Dymock RB, McCarthy PJ, Grose $\mathrm{RH}$, Cummins AG. The role of small intestinal bacterial overgrowth, intestinal permeability, endotoxaemia, and tumour necrosis factor alpha in the pathogenesis of non-alcoholic steatohepatitis. Gut 2001;48:206-211.

50. Shanab AA, Scully P, Crosbie O, Buckley M, O'Mahony L, Shanahan $F$, et al. Small intestinal bacterial overgrowth in nonalcoholic steatohepatitis: association with toll-like receptor 4 expression and plasma levels of interleukin 8. Dig Dis Sci 2011;56:1524-1534.

51. Yoshimoto S, Loo TM, Atarashi K, Kanda H, Sato S, Oyadomari S, et al. Obesity-induced gut microbial metabolite promotes liver cancer through senescence secretome. Nature 2013;499:97-101.

52. Dapito DH, Mencin A, Gwak GY, Pradere JP, Jang MK, Mederacke I, et al. Promotion of hepatocellular carcinoma by the intestinal microbiota and TLR4. Cancer Cell 2012;21:504-516.

53. Tang R, Liu H, Yuan Y, Xie K, Xu P, Liu X, et al. Genetic factors associated with risk of metabolic syndrome and hepatocellular carcinoma. Oncotarget 2017;8:35403-35411.

54. Sookoian S, Pirola CJ. Meta-analysis of the influence of I148M variant of patatin-like phospholipase domain containing 3 gene (PNPLA3) on the susceptibility and histological severity of nonalcoholic fatty liver disease. Hepatology 2011;53:1883-1894.

55. Ueyama M, Nishida N, Korenaga M, Korenaga K, Kumagai E, Yanai H, et al. The impact of PNPLA3 and JAZF1 on hepatocellular carcinoma in non-viral hepatitis patients with type 2 diabetes mellitus. J Gastroenterol 2016;51:370-379.

56. Liu YL, Reeves HL, Burt AD, Tiniakos D, McPherson S, Leathart JB, 
et al. TM6SF2 rs58542926 influences hepatic fibrosis progression in patients with non-alcoholic fatty liver disease. Nat Commun 2014;5:4309.

57. Kessler S, Simon Y, Gemperlein K, Gianmoena K, Cadenas C, Zimmer $V$, et al. Fatty acid elongation in non-alcoholic steatohepatitis and hepatocellular carcinoma. Int J Mol Sci 2014;15:5762.

58. Sorrentino P, D’Angelo S, Ferbo U, Micheli P, Bracigliano A, Vecchione R. Liver iron excess in patients with hepatocellular carcinoma developed on non-alcoholic steato-hepatitis. J Hepatol 2009;50:351357.

59. Dongiovanni P, Fracanzani AL, Fargion S, Valenti L. Iron in fatty liver and in the metabolic syndrome: a promising therapeutic target. J Hepatol 2011;55:920-932.
60. Shim JJ. Body iron, serum ferritin, and nonalcoholic fatty liver disease. Korean J Hepatol 2012;18:105-107.

61. Kowdley KV, Belt P, Wilson LA, Yeh MM, Neuschwander-Tetri BA, Chalasani $N$, et al. Serum ferritin is an independent predictor of histologic severity and advanced fibrosis in patients with nonalcoholic fatty liver disease. Hepatology 2012;55:77-85.

62. Dunn W, Sanyal AJ, Brunt EM, Unalp-Arida A, Donohue M, McCullough AJ, et al. Modest alcohol consumption is associated with decreased prevalence of steatohepatitis in patients with nonalcoholic fatty liver disease (NAFLD). J Hepatol 2012;57:384-391.

63. Farges O, Ferreira N, Dokmak S, Belghiti J, Bedossa P, Paradis V. Changing trends in malignant transformation of hepatocellular adenoma. Gut 2011;60:85-89. 